\title{
Historical analysis of epizootiological situation of rabies on the territory of the Slovak Republic
}

\author{
A. ONDREJKOVÁ ${ }^{1}$, Š. ŠVRČEK ${ }^{1}$, R. ONDREJKA ${ }^{1}$, Z. BENÍŠEK ${ }^{1+}$, J. SÜLI² ${ }^{2}$ V. KOPŘIVA ${ }^{3}$, \\ S. ZEMANOVÁ1, Z. BENKÖ ${ }^{1}, \mathrm{~L}^{\prime}$. KORYTÁR ${ }^{1 *}$
}

\begin{abstract}
${ }^{1}$ Department of Epizootiology and Parasitology, University of Veterinary Medicine and Pharmacy in Košice, Komenského 73, 04181 Košice, Slovak Republic; ${ }^{2}$ Department of Chemistry, Biochemistry and Biophysics, University of Veterinary Medicine and Pharmacy in Košice, Košice, Slovak Republic; ${ }^{3}$ State Veterinary and Food Administration of the Slovak Republic, Bratislava, Slovak Republic
\end{abstract}

\begin{abstract}
Summary. - Currently, Slovakia is a rabies-free country, but the epizootiological situation of rabies was not always favorable. The main reservoir species of rabies virus in the first half of the last century was the domestic dog. Since 1906, hundreds of cases were reported, of which approximately $90 \%$ were infected dogs. The disease had a typical urban character. Since 1929, the number of rabid domestic animals decreased due to the implementation of dog vaccination campaigns in particular parts of Slovakia. From the second half of 1950s, red foxes (Vulpes vulpes) have become an important reservoir of the RABV. In this time period urban rabies in Slovakia changed into sylvatic form. One effective method of prevention and control of wildlife rabies is an oral rabies vaccination of red foxes. It is carried out in Slovakia since 1993. A detailed development of the rabies epizootiological situation on the territory of the Slovak Republic until the application of oral antirabies immunisation of foxes and the current situation after its performance is the main object of this review.
\end{abstract}

Keywords: rabies; Lyssavirus; red fox; incidence; oral vaccination

\section{Introduction}

Rabies is an acute, progressive infectious disease of the central nervous system (CNS) of homoiothermic animals, including human. Lyssa, which means "mad" or "violent", is the ancient Greek name for rabies. The existence of the disease resembling rabies is mentioned in records older than 5,000 years. The first historic evidence describing illness after bites by dogs recorded ancient Egyptians and Mesopotamians in their written texts (Blaisdell, 1994).

Except for Antarctica and a few rabies-free island territories, rabies occurs on all continents (Hanlon and Childs, 2013).

"Corresponding author.E-mail:korytar.uvm@gmail.com; phone: +421-907 816 472. ${ }^{\dagger}$ Deceased author.

Abbreviations: CNS $=$ central nervous system; ICTV $=$ International Committee on Taxonomy of Viruses; RABV = rabies virus; SVFA = State Veterinary and Food Administration of the Slovak Republic
From the global point of view, the rabies poses one of the most important threats for the public health. Nevertheless, the rabies belongs to the neglected zoonotic diseases with a highest incidence among humans and susceptible animal species in Africa and Asia (Fooks et al., 2014). Approximately 50,000-60,000 people die from rabies each year (Wunner and Briggs, 2010).

Rabies is caused by a negative stranded RNA virus belonging to the genus Lyssavirus in the family Rhabdoviridae of the order Mononegavirales. All lyssaviruses are neurotropic pathogens (Fooks et al., 2017).

According to ICTV (2019), the genus Lyssavirus includes 16 recently known and classified viruses. Phylogenetic analyses targeted on lyssaviruses distinguish two genetically and immunopathologically distinct phylogroups (Badrane et al., 2001). Phylogroup I includes Rabies lyssavirus (RABV), Australian bat lyssavirus (ABLV), Duvenhage lyssavirus (DUVV), European bat 1 lyssavirus (EBL-1), European bat 2 lyssavirus (EBL-2), Aravan lyssavirus (ARAV), Khujand lyssavirus (KHUV), Bokeloh bat 
Table 1. Geographical distribution and reservoirs of classified lyssaviruses (ICTV, 2019)

\begin{tabular}{|c|c|c|c|}
\hline Genotype & Species & Distribution & Reservoir \\
\hline 1 & Rabies virus & Worldwide & Carnivora Chiroptera \\
\hline 2 & Lagos bat virus & Sub-Saharan Africa & Chiroptera \\
\hline 3 & Mokola virus & Sub-Saharan Africa & unknown \\
\hline 4 & Duvenhage virus & South Africa & Chiroptera \\
\hline 5 & European bat lyssavirus 1 & Europe & Chiroptera \\
\hline 6 & European bat lyssavirus 2 & Europe & Chiroptera \\
\hline 7 & Australian bat lyssavirus & Australia & Chiroptera \\
\hline- & Aravan virus & Central Asia & Chiroptera \\
\hline- & Khujand virus & Central Asia & Chiroptera \\
\hline- & Irkut virus & East Siberia & Chiroptera \\
\hline- & West Caucasian bat virus & Caucasus & Chiroptera \\
\hline- & Ikoma lyssavirus & East Africa & African Civet (Civettictis civetta) \\
\hline- & Shimoni bat virus & East Africa & Chiroptera \\
\hline- & Bokeloh bat lyssavirus & Europe & Chiroptera \\
\hline- & Gannoruwa bat lyssavirus & East Asia & Chiroptera \\
\hline- & Lleida bat lyssavirus & Europe & Chiroptera \\
\hline
\end{tabular}

lyssavirus (BBLV), Irkut lyssavirus (IRKV) and Gannoruwa bat lyssavirus (GBLV).

Phylogroup II includes Lagos bat lyssavirus (LBV), Mokola lyssavirus (MOKV) and Shimoni bat lyssavirus (SHIBV).

Ikoma lyssavirus (IKOV), Lleida bat lyssavirus (LLBV) and West Caucasian bat lyssavirus (WCBV) are not included into phylogroups now.

Two novel lyssaviruses, Taiwan bat lyssavirus (TBLV) (Hu et al., 2018) and Kotalahti bat lyssavirus (KBLV) (Norieki et al., 2018) are not classified up to date (ICTV, 2019). Mammalian reservoirs include carnivores (Carnivora) and bats (Chiroptera). The known reservoir organisms and geographical distribution of all classified lyssaviruses are summarised in the Table 1.

The RABV circulating in dogs is responsible for more than $99 \%$ of human infections worldwide (Knobel et al., 2005). Lyssaviruses are most often transmitted by the bite or by a scratch of an infected animal. In this way, the virus crosses the dermal barrier and reaches the tissue of a susceptible host, where it can begin to spread (Jeffries et al., 2013). After reaching the motor neurons, the lyssavirus propagates up to the CNS. Lyssavirus follows neuronal connections in the organism of its host, which protects the virus from the immune system of the infected macroorganism (Johnson et al., 2010). In the CNS, the lyssavirus replicates and disseminates to almost all compartments of the system.

In addition to the most common route of infection by a bite, other ways of transmission of lyssaviruses have been described. Crandell (1991) reported RABV infection in Polar Foxes (Vulpes lagopus) via consumption of infected carcasses. (Anderson et al., 1984) described a contact with mucosa as another possible way of RABV infection. Transmission of lyssaviruses by aerosol was also recorded (Constantine, 1962; Johnson et al., 2006). Transmission between dead-end hosts including human occurs under exceptional conditions in cases of organ or corneal transplantations (Maier et al., 2010). RABV may be secreted to the breast milk (Dutta, 1998). Transplacental transmission has been reported in animals but has not been documented in humans (Singh et al., 2017).

Rabies of humans and animals is preventable by vaccines. Approximately 15 million people receive rabies post-exposure prophylaxis annually (Wilde et al., 2013).

In countries, where canine rabies has been eliminated, wild animals like foxes, raccoons and skunks are still important reservoir species. For this reason, these species pose an important target of vaccination campaigns (Dietzschold et al., 2004).

Until now, especially for the species at risk of rabies virus infection, prophylactic and pre-exposition vaccinations remain the main and sole approach to prevent the disease (Franka et al., 2009).

Inactivated rabies vaccines, which are known for their safety, represent an important tool for rabies control (Hampson et al., 2011). In Europe and North America, several live attenuated rabies vaccines such as SAD B19, SAG-1 and SAG-2 (Muller et al., 2009; Prager et al., 2011) have been successfully applied as pre-exposure prophylaxis by oral immunisation of wildlife. These vaccines are derived from the Street Alabama Dufferin (SAD) field strain isolated from a dog in North America in 1935 (Geue et al., 2008). 


\section{Epizootiological situation of rabies at the beginning of the 20 th century}

The first rabies cases on the territory of the Slovak Republic were identified at the end of the $19^{\text {th }}$ century, involving rabies cases of dogs and cats. The urban rabies form occurred in Slovakia prior to the Second World War; as is evident from the high number of people treated after exposure to rabid dogs in the Pasteur Institute of the State Hospital in Košice (Strimpl, 1931; Jiroušková et al., 1990) (Table 2). The main reservoir species of the rabies virus in the first half of the last century was the domestic dog. The rabies cases in dogs accounted for almost $90 \%$ of those confirmed to be positive. In the former Czechoslovakia, 132 people died from rabies and 25,000 people were postexposure vaccinated between 1919 and 1937. Most cases of rabies have been reported in domestic carnivores and livestock in villages and small towns. Data on the occur-

Table 2. Number of human patients in the Pasteur Hospital in Košice (Czechoslovakia) from 1928 to 1930 (Jiroušková et al., 1990)

\begin{tabular}{lccc}
\hline Number of: & $\begin{array}{c}\mathbf{1 9 2 8} \\
\text { (8 months) }\end{array}$ & $\mathbf{1 9 2 9}$ & $\mathbf{1 9 3 0}$ \\
\hline Accepted patients & 894 & 976 & 676 \\
Treated patients & 884 & 970 & 672 \\
Bited by health dogs & 86 & 155 & 127 \\
Bited by rabid dogs & 334 & 391 & 223 \\
Bited by unknown dogs & 310 & 290 & 186 \\
Contact with infected animal & 110 & 134 & 51 \\
Patient who drank milk from & 32 & - & 81 \\
rabid cows & & & \\
$\begin{array}{l}\text { Patient who dissected cadavers } \\
\text { of rabid cows and was teared }\end{array}$ & 12 & - & 4 \\
\hline
\end{tabular}

rence of rabies in Slovakia at that time are incomplete, but we can assume that the epidemiological situation in rabies was the same as in Central Europe (Matouch et al., 1998).

The disease had a typical urban character; domestic dogs were considered the main reservoir of rabies. At that time, veterinary measures focused on the elimination of suspicious and stray dogs and cats (Matouch et al., 2002). According to our data, rabies in wild animals was not a problem, so it received little attention. Bites by rabid animals other than dogs were rare (Jiroušková et al., 1990).

The diagnosis of rabies was initially performed only on the basis of clinical signs or necropsy of dead animals. Laboratory diagnostics of rabies began in 1920 at the State Diagnostic and Serotherapeutic Veterinary Institute at Ivanovice na Hané. However, the capacity of this laboratory was only sufficient to test domestic animals and humans (Strimpl, 1931).

Since 1929, the number of rabies cases in domestic animals has been gradually decreasing, 608 cases in 1928 (519 dogs, 47 cats, 32 cattle, 2 goats), 455 cases in 1929 ( 401 dogs, 24 cats and 30 other domestic animals) and 33 in 1939 (Table 3). The reduction was achieved by large vaccination campaigns of dogs in some parts of Slovakia and Bohemia during 1929-1931 (Ursíny and Stolzová-Sutorisová, 1970).

There was little interest in wildlife from the point of view of veterinary and public services; although high fox mortality was observed occasionally, e.g. 1919-1920, foxes were not investigated in the laboratory and the etiology remained unexplained. We found no information about rabies in wild animals between 1919 and 1939 in historical records, although Ursíny and Stolzová-Sutorisová (1970) claimed that rabies was sporadically recorded in foxes and wolves in eastern parts of Slovakia and western Ukraine. Despite a slight increase in 1935-1937, the overall epide-

Table 3. Laboratory confirmed cases of rabies from 1906 to 1939 (Ursíny and Stolzová-Sutorisová, 1970)

\begin{tabular}{|c|c|c|c|c|c|c|c|c|c|}
\hline Year & Dogs & Cats & Others & $\Sigma$ & Year & Dogs & Cats & Others & $\Sigma$ \\
\hline 1906 & 387 & 0 & 0 & 387 & 1928 & 519 & 47 & 42 & 608 \\
\hline 1907 & 337 & 7 & 2 & 346 & 1929 & 401 & 24 & 30 & 455 \\
\hline 1908 & 887 & 0 & 0 & 887 & 1930 & 203 & 10 & 11 & 224 \\
\hline 1909 & 519 & 5 & 26 & 550 & 1931 & 162 & 9 & 9 & 180 \\
\hline 1910 & 568 & 0 & 6 & 574 & 1932 & 95 & 1 & 0 & 96 \\
\hline \multicolumn{5}{|c|}{ Data not available } & 1933 & 76 & 7 & 5 & 88 \\
\hline 1919 & 333 & 26 & 6 & 365 & 1934 & 47 & 2 & 3 & 52 \\
\hline 1920 & 151 & 9 & 2 & 162 & 1935 & 76 & 2 & 5 & 83 \\
\hline \multicolumn{5}{|c|}{ Data not available } & 1936 & 89 & 3 & 4 & 96 \\
\hline 1924 & 533 & 52 & 49 & 634 & 1937 & 78 & 2 & 11 & 91 \\
\hline 1925 & 483 & 36 & 29 & 548 & 1938 & 41 & 4 & 2 & 47 \\
\hline 1926 & 472 & 37 & 27 & 536 & 1939 & 32 & 0 & 1 & 33 \\
\hline 1927 & 382 & 26 & 47 & 455 & Summary & 6871 & 309 & 317 & 7497 \\
\hline
\end{tabular}

$\Sigma$ - total number of rabies cases in a particular year. 
miological situation in rabies stabilized (Matouch et al., 2002).

No records from the years 1940-1947 were preserved, as the Institute for rabies diagnostics was seriously damaged during the war. After the war, the incidence of rabies increased, most cases were diagnosed in winter, from January to April and the lowest incidence was in July to September, the incidence of rabies was bound to the borderline and nearby regions in Moravia and Slovakia (Matouch et al., 2007).

The epidemiological situation changed after the Second World War, when the immunisation of dogs against rabies started. Immunisation was voluntary since 1927, becoming obligatory in 1953.

Cases of rabies in domestic carnivores (mainly dogs) were gradually replaced with cases in wild carnivores (foxes and wolves). This is confirmed by the incidence of rabies in individual animal species: from 1921 to 1943 , confirmed positive cases of rabies in dogs presented 89.3\% of the total and in wild animals only $0.04 \%$.

Most cases of rabies have been diagnosed in foxes since the second half of the 1950s. It was in this period that the urban form of rabies changed to sylvatic, which clearly required a change in the strategy to combat this severe zoonosis (Müller et al., 1998). Wild animals have become the reservoir of rabies in Europe, especially foxes, which played a key role in the exposure of domestic animals. At the same time, their share of human exposure increased (Matouch and Vitásek, 2002).

From 1945 to 1960 the epizootiological situation in Slovakia changed, with rabies being diagnosed in dogs only in $9 \%$ of the total number of confirmed cases and in $80.1 \%$ in wild animals; $93.3 \%$ of them were foxes (Ursíny and Stolzová-Sutorisová, 1970) (Table 4). The total number of confirmed cases sharply dropped during this period.

The rabies epizootiological situation worsened from the second half of the 1960s; more than 300 positive cases were confirmed just in 1968. The number of positive cases constantly increased until the end of 1980 s. Almost 7,000 rabies cases and 2 cases of bat lyssavirus infection (Švrček et al., 1991; 2001; Ondrejková et al., 2004) were recorded in Slovakia in the last 25 years. The last case of human rabies in Slovakia was identified in 1990 (Švrček et al., 1999).

All measures adopted during the 1970s and 1980s and directed at the reduction of population density of foxes the main reservoir species of rabies (payment of shooting

Table 4. Rabies cases in domestic and wild animals in the Slovak Republic from 1947 to 1992 (Ursíny and Stolzová-Sutorisová, 1970; Ondrejková et al., 2004)

\begin{tabular}{|c|c|c|c|c|c|c|c|}
\hline Year & DA & WA & $\mathbf{n}$ & Year & DA & WA & $\mathbf{n}$ \\
\hline 1947 & 16 & 1 & 17 & 1970 & 81 & 182 & 263 \\
\hline 1948 & 5 & 0 & 5 & 1971 & 90 & 157 & 247 \\
\hline 1949 & 2 & 0 & 2 & 1972 & 121 & 206 & 327 \\
\hline 1950 & 0 & 1 & 1 & 1973 & 47 & 143 & 190 \\
\hline 1951 & 13 & 16 & 29 & 1974 & 73 & 133 & 206 \\
\hline 1952 & 8 & 1 & 9 & 1975 & 69 & 60 & 129 \\
\hline 1953 & 8 & 4 & 12 & 1976 & 62 & 98 & 160 \\
\hline 1954 & 11 & 10 & 21 & 1977 & 54 & 121 & 175 \\
\hline 1955 & 0 & 1 & 1 & 1978 & 39 & 90 & 129 \\
\hline 1956 & 1 & 0 & 1 & 1979 & 46 & 22 & 68 \\
\hline 1957 & 1 & 0 & 1 & 1980 & 19 & 34 & 53 \\
\hline 1958 & 4 & 5 & 9 & 1981 & 8 & 39 & 47 \\
\hline 1959 & 2 & 1 & 3 & 1982 & 47 & 66 & 113 \\
\hline 1960 & 6 & 9 & 15 & 1983 & 42 & 114 & 156 \\
\hline 1961 & 6 & 14 & 20 & 1984 & 51 & 161 & 212 \\
\hline 1962 & 10 & 56 & 66 & 1985 & 42 & 66 & 108 \\
\hline 1963 & 11 & 75 & 86 & 1986 & 39 & 122 & 161 \\
\hline 1964 & 4 & 104 & 108 & 1987 & 41 & 117 & 158 \\
\hline 1965 & 3 & 84 & 87 & 1988 & 34 & 204 & 238 \\
\hline 1966 & 10 & 67 & 77 & 1989 & 29 & 182 & 211 \\
\hline 1967 & 15 & 145 & 160 & 1990 & 40 & 187 & 227 \\
\hline 1968 & 77 & 324 & 401 & 1991 & 40 & 165 & 205 \\
\hline \multirow[t]{2}{*}{1969} & 20 & 120 & 140 & 1992 & 44 & 258 & 302 \\
\hline & & & & Summary & 1391 & 3965 & 5356 \\
\hline
\end{tabular}

$\mathrm{DA}=$ rabies cases in domestic animals, $\mathrm{WA}=$ rabies cases in wild animals. 
premium, gassing of the fox lairs, poisoning of foxes by strychnine baits, sterilization of foxes by baits) - showed to be ineffective (Švrček et al., 1995).

\section{Oral immunisation of red foxes against rabies in Slovak Republic}

The idea of immunisation of foxes against rabies was expressed by prof. Baer in the early 1960s. One effective method of rabies control of wild animals is the oral vaccination of red foxes against rabies (Wandeler, 2000). The current rabies epizootiological situation not only in Slovakia, but also in other European states, is closely associated with its performance or non-performance. Oral immunisation must be carried out with due regard to the specific conditions of each country. The basic prerequisite for successful oral anti-rabies vaccination in wild animals was a detailed elaboration of the strategy of implementation of individual vaccination campaigns aimed at eliminating rabies in large territorial units (Müller et al., 1998).

According to the WHO and OIE recommendations, the oral immunisation of free-living red foxes against rabies is of great importance in the control of fox rabies. It is a pre-emptive, effective, ecologically harmless, financially and technically manageable measure. By 1994, oral anti- rabies vaccination had begun in 17 European countries, with about 15 million vaccine doses distributed annually (Stöhr and Meslin, 1996).

The oral vaccination of red foxes against rabies in Slovakia began in 1992 (Švrček, 1992; Švrček et al., 1995; Durove et al., 1996a) based on the resolution of the State Veterinary Administration of the Slovak Republic in Bratislava, in co-operation with Mevak Inc. Nitra, Associated Laboratory for Rabies Research of University of Veterinary Medicine and Institute of Experimental Veterinary Medicine in Košice, the Hunting Association, the State Veterinary Institutes and other related institutes. The oral vaccination of red foxes against rabies was performed in selected areas of the Slovak Republic in 1992 and 1993 in two phases (spring and autumn). The oral vaccine Kamark (Mevak Inc. Nitra, Slovak Republic) was used (Švrček et al., 1993, 1998).

After detailed evaluation of the efficacy of oral vaccination in selected areas, a program of vaccination for the whole republic for 1994-1996 was elaborated. Besides vaccine Kamark, the vaccine Lysvulpen (Bioveta Inc., Ivanovice na Hané, Czech Republic) was also used in the spring campaign in 1994 (Table 5). The effectiveness of its implementation was shown after just the first year, when the number of positive cases of rabies decreased to $50 \%$. In 1997 , a nationwide anti-rabies vaccination of red foxes was discontinued, resulting in an increase in

Table 5. Oral rabies vaccination of free-living red foxes in Slovak Republic from 1992 to 1996 (Kopřiva et al., 2009)

\begin{tabular}{|c|c|c|c|c|c|}
\hline \multirow{2}{*}{ Year } & \multirow{2}{*}{ Campaign } & \multicolumn{3}{|c|}{ Vaccination baits } & \multirow{2}{*}{ Treated area $\left(\mathrm{km}^{2}\right)$} \\
\hline & & Sort & Producer & Number & \\
\hline 1992 & Spring/Autumn & Kamark & Mevak Inc., SR & 30,000 & 2,000 \\
\hline 1993 & Spring/Autumn & Kamark & Mevak Inc., SR & 100,300 & 6,687 \\
\hline 1994 & Spring/Autumn & $\begin{array}{c}\text { Kamark } \\
\text { Lysvulpen }\end{array}$ & $\begin{array}{l}\text { Mevak Inc., SR } \\
\text { Bioveta Inc., ČR }\end{array}$ & 650,000 & 47,000 \\
\hline 1995 & Spring/Autumn & Kamark & Mevak Inc., SR & 650,000 & 47,000 \\
\hline 1996 & Spring/Autumn & Kamark & Mevak Inc., SR & 552,800 & 36,400 \\
\hline
\end{tabular}

Table 6. Occurrence of rabies in domestic and wild animals in Slovakia from 1993 to 1999 (Ďurove et al., 1992b; Kopřiva et al., 2009)

\begin{tabular}{|c|c|c|c|c|c|c|c|}
\hline \multirow{2}{*}{ Year } & \multicolumn{2}{|c|}{ Domestic animals } & \multicolumn{4}{|c|}{ Wild animals } & \multirow{2}{*}{ Total } \\
\hline & total & $\%$ & foxes & $\%$ & total & $\%$ & \\
\hline 1993 & 80 & 16.4 & 393 & 80.4 & 409 & 83.6 & 489 \\
\hline 1994 & 113 & 20.0 & 428 & 75.7 & 452 & 80.0 & 565 \\
\hline 1995 & 62 & 23.3 & 197 & 74.0 & 204 & 76.7 & 266 \\
\hline 1996 & 73 & 21.2 & 256 & 74.2 & 272 & 78.8 & 345 \\
\hline 1997 & 52 & 20.0 & 198 & 76.4 & 207 & 80.0 & 259 \\
\hline 1998 & 67 & 16.2 & 336 & 81.2 & 347 & 83.8 & 414 \\
\hline 1999 & 83 & 16.5 & 392 & 77.9 & 420 & 83.5 & 503 \\
\hline Summary & 530 & 18.7 & 2200 & 77.4 & 2311 & 81.3 & 2841 \\
\hline
\end{tabular}


positive cases of rabies until 1999. In 1997-1998, the oral immunisation against rabies was renewed in selected areas of the Slovak Republic, especially in areas of rabies prevalence (Kopřiva et al., 2009).

A total of 413 cases were reported in 1998, of which $16 \%$ were infected domestic animals and $84 \%$ were infected wild animals (Table 6). Numerous outbreaks were spread throughout the territory, with the highest concentration in the southwestern area, near the borders with Austria and Hungary.

The State Veterinary and Food Administration of the Slovak Republic (SVFA) developed a triennial program of oral immunisation against rabies in 1999, specifically for the period of 2000-2002 (Hlinka, 2002). In the spring of 2000 , the whole territory of the Slovak Republic was vaccinated by air, only in several districts the vaccination baits were spread manually. The vaccine Lysvulpen (Bioveta Inc., Ivanovice na Hané, Czech Republic) was used; the vaccinated area was $30,000 \mathrm{~km}^{2}$ (Table 7 ). In the autumn of 2000 an additional Lyssavac vaccine (Pharmagal Bio Ltd. Nitra, Slovak Republic) was used (Table 7) (Kopřiva et al., 2009).

In the year 2001, the two oral rabies vaccines mentioned above were used again. The whole territory of the country was vaccinated by air, with the exception of a small area and some suburban districts, where the vaccination baits were spread manually (Kopřiva et al., 2009). In the autumn campaign of 2002 and the spring of 2003, a new rabies oral vaccine Lyssagal cps. a.u.v. (Pharmagal Bio Ltd. Nitra, Slovak Republic) was used (Hlinka, 2002).

Due to aggravation of the epizootiological situation in rabies, protocols for oral vaccination against rabies were re-evaluated and the oral vaccine used was changed (SVFA, 2003). The vaccine Lysvulpen (Bioveta Inc. Ivanovice na Hané, Czech Republic) has been used for oral vaccination against rabies on the territory of Slovakia since autumn 2003.

The oral immunisation control is performed according to the instructions for use elaborated by SVFA of the Slovak Republic before each vaccination campaign. Not only the vaccine, but also the baits for oral immunisation of wild animals must fulfil a complex series of recommendations (Wandeler, 1991; Švrček, 1992).

One of the first field control examinations is the control of the acceptance of vaccination baits, because the ingestion of the majority of spread baits by the target animals - red foxes - over a period of 3-5 days indicates

Table 7. Oral anti-rabies vaccination of free-living red foxes and vaccines used in the Slovak Republic from 2000 to 2019 (Kopřiva et al., 2009; Kopřiva unpublished data)

\begin{tabular}{|c|c|c|c|c|c|}
\hline \multirow{2}{*}{ Year } & \multirow{2}{*}{ Campaign } & \multicolumn{3}{|c|}{ Vaccination baits } & \multirow{2}{*}{ Treated area $\left(\mathbf{k m}^{2}\right)$} \\
\hline & & Vaccine & Producer & Number & \\
\hline 2000 & $\mathrm{~S} / \mathrm{A}$ & $\begin{array}{l}\text { Lysvulpen } \\
\text { Lyssavac }\end{array}$ & $\begin{array}{l}\text { Bioveta Inc. } \\
\text { CR Pharmagal Bio Ltd. }\end{array}$ & 675,180 & 30,000 \\
\hline 2001 & $\mathrm{~S} / \mathrm{A}$ & $\begin{array}{l}\text { Lysvulpen } \\
\text { Lyssavac }\end{array}$ & $\begin{array}{l}\text { Bioveta Inc. } \\
\text { CR Pharmagal Bio Ltd. }\end{array}$ & 767,180 & 30,000 \\
\hline 2002 & $\mathrm{~S} / \mathrm{A}$ & $\begin{array}{l}\text { Lyssavac } \\
\text { Lyssagal }\end{array}$ & Pharmagal Bio Ltd. & 798,600 & 32,422 \\
\hline 2003 & S/A & Lysvulpen & Bioveta Inc., CR & 700,000 & 33,250 \\
\hline 2004 & S/A & Lysvulpen & Bioveta Inc., CR & 876,000 & 33,250 \\
\hline 2005 & S/A & Lysvulpen & Bioveta Inc., CR & 844,900 & 13,800 \\
\hline 2006 & $\mathrm{~S} / \mathrm{A}$ & Lysvulpen & Bioveta Inc., CR & 844,900 & 12,000 \\
\hline 2007 & S/A & Lysvulpen & Bioveta Inc., CR & 844,900 & 12,000 \\
\hline 2008 & S/A & Lysvulpen & Bioveta Inc., CR & 844,900 & 12,000 \\
\hline 2009 & $\mathrm{~S} / \mathrm{A}$ & Lysvulpen & Bioveta Inc., CR & NA & NA \\
\hline 2010 & $\mathrm{~S} / \mathrm{A}$ & Lysvulpen & Bioveta Inc., CR & NA & NA \\
\hline 2011 & S/A & Lysvulpen & Bioveta Inc., CR & NA & NA \\
\hline 2012 & S/A & Lysvulpen & Bioveta Inc., CR & NA & NA \\
\hline 2013 & S/A & Lysvulpen & Bioveta Inc., CR & NA & NA \\
\hline 2014 & S/A & Lysvulpen & Bioveta Inc., CR & NA & NA \\
\hline 2015 & S/A & Lysvulpen & Bioveta Inc., CR & NA & NA \\
\hline 2016 & S/A & Lysvulpen & Bioveta Inc., CR & 614,050 & 12,458 \\
\hline 2017 & S/A & Lysvulpen & Bioveta Inc., CR & 620,300 & 12,458 \\
\hline 2018 & S/A & Lysvulpen & Bioveta Inc., CR & 632,800 & 12,708 \\
\hline 2019 & S/A & Lysvulpen & Bioveta Inc., CR & 632,800 & 12,708 \\
\hline
\end{tabular}

$\mathrm{S}=$ summer, $\mathrm{A}=$ autumn, $\mathrm{NA}=$ data not available. 
Table 8. Rabies in domestic and wild animals including foxes in Slovakia from 2000 to 2019 (Kopřiva et al., 2009; SVFA, 2019)

\begin{tabular}{|c|c|c|c|c|c|c|c|}
\hline \multirow{2}{*}{ Years } & \multicolumn{2}{|c|}{ Domestic animals } & \multicolumn{4}{|c|}{ Wild animals } & \multirow{2}{*}{ Total } \\
\hline & total & $\%$ & foxes & $\%$ & total & $\%$ & \\
\hline 2000 & 71 & 20.2 & 267 & 76.0 & 280 & 79.8 & 351 \\
\hline 2001 & 12 & 13.8 & 70 & 80.4 & 75 & 86.2 & 87 \\
\hline 2002 & 19 & 16.8 & 90 & 79.6 & 94 & 83.2 & 113 \\
\hline 2003 & 42 & 12.9 & 247 & 75.8 & 284 & 87.1 & 326 \\
\hline 2004 & 4 & 6.2 & 54 & 84.4 & 60 & 93.8 & 64 \\
\hline 2005 & 4 & 8.0 & 44 & 88.0 & 46 & 92.0 & 50 \\
\hline 2006 & 0 & 0 & 4 & 100.0 & 4 & 100.0 & 4 \\
\hline 2007-2012 & 0 & 0 & 0 & 0 & 0 & 0 & $\mathbf{0}$ \\
\hline 2013 & 2 & 28.6 & 4 & 57.1 & 5 & 71.4 & 7 \\
\hline 2014 & 0 & 0 & 0 & 0 & 0 & 0 & $\mathbf{0}$ \\
\hline 2015 & 0 & 0 & 5 & 100.0 & 5 & 100.0 & 5 \\
\hline 2016-2019 & 0 & 0 & 0 & 0 & 0 & 0 & $\mathbf{0}$ \\
\hline Summary & 154 & 15.3 & 785 & 77.9 & 853 & 84.7 & 1007 \\
\hline
\end{tabular}

Table 9. Summary of wild and domestic animals tested for rabies in Slovakia from 2000 to 2019 (Kopřiva et al., 2009; SVFA, 2019)

\begin{tabular}{|c|c|c|c|c|c|c|c|c|c|c|}
\hline \multirow{3}{*}{ Year } & \multicolumn{4}{|c|}{ Wild animals } & \multicolumn{4}{|c|}{ Domestic animals } & \multirow{2}{*}{\multicolumn{2}{|c|}{$\begin{array}{c}\text { Total No. of tested } \\
\text { animals }\end{array}$}} \\
\hline & \multicolumn{2}{|c|}{ Foxes } & \multicolumn{2}{|c|}{ Others } & \multicolumn{2}{|c|}{ Dogs \& cats } & \multicolumn{2}{|c|}{$\begin{array}{l}\text { Others } \\
\end{array}$} & & \\
\hline & + & - & + & - & + & - & + & - & + & - \\
\hline 2019* & 0 & 555 & 0 & 29 & 0 & 108 & 0 & 8 & 0 & 700 \\
\hline 2018 & 0 & 699 & 0 & 42 & 0 & 151 & 0 & 6 & 0 & 898 \\
\hline 2017 & 0 & 1743 & 0 & 61 & 0 & 163 & 0 & 8 & 0 & 1975 \\
\hline 2016 & 0 & 1716 & 0 & 51 & 0 & 172 & 0 & 7 & 0 & 1946 \\
\hline 2015 & 5 & 1874 & 0 & 33 & 0 & 217 & 0 & 9 & 5 & 2133 \\
\hline 2014 & 0 & 1396 & 0 & 32 & 0 & 226 & 0 & 10 & 0 & 1664 \\
\hline 2013 & 4 & 3535 & 1 & 45 & 2 & 213 & 0 & 4 & 7 & 3797 \\
\hline 2012 & 0 & 3369 & 0 & 44 & 0 & 242 & 0 & 13 & 0 & 3668 \\
\hline 2011 & 0 & 3264 & 0 & 60 & 0 & 279 & 0 & 20 & 0 & 3623 \\
\hline 2010 & 0 & 2922 & 0 & 42 & 0 & 323 & 0 & 16 & 0 & 3303 \\
\hline 2009 & 0 & 3203 & 0 & 86 & 0 & 391 & 0 & 28 & 0 & 3708 \\
\hline 2008 & 0 & 3422 & 0 & 77 & 0 & 484 & 0 & 25 & 0 & 4008 \\
\hline 2007 & 0 & 3751 & 0 & 86 & 0 & 445 & 0 & 31 & 0 & 4313 \\
\hline 2006 & 1 & 3630 & 0 & 105 & 0 & 485 & 0 & 21 & 1 & 4241 \\
\hline 2005 & 44 & 1767 & 2 & 126 & 4 & 654 & 0 & 42 & 50 & 2589 \\
\hline 2004 & 54 & 1563 & 6 & 109 & 3 & 660 & 1 & 50 & 64 & 2382 \\
\hline 2003 & 295 & 1791 & 13 & 159 & 43 & 676 & 3 & 72 & 354 & 2698 \\
\hline 2002 & 94 & 1452 & 3 & 130 & 16 & 713 & 1 & 80 & 114 & 2375 \\
\hline 2001 & 72 & 1027 & 4 & 116 & 11 & 674 & 0 & 62 & 87 & 1879 \\
\hline 2000 & 292 & 1416 & 13 & 164 & 66 & 793 & 4 & 69 & 375 & 2442 \\
\hline Summary & 861 & 44095 & 42 & 1597 & 145 & 8069 & 9 & 581 & 1057 & 54342 \\
\hline
\end{tabular}

$(+)=$ No. of infected animals, $(-)=$ No. of non-infected animals, $\left(^{*}\right)=$ in 2019 data available only until June $30^{\text {th }}$.

their attractiveness (Wandeler, 1991). Laboratory investigations are an integral part of effectiveness and quality verification; this step is primarily conditioned by controlled shooting of young foxes in the vaccination zone (Ondrejková et al., 2000).

\section{The current epizootiological situation in the Slovak Republic}

The reduction of rabies incidence in domestic and wild animals is achieved by the epizootiological effectiveness of oral immunisation against rabies over the entire terri- 
tory of the country. In 1995 the number of positive rabies cases in wild animals, particularly in red foxes, markedly decreased (Table 6) following the first whole-territory oral vaccination against rabies (Durove et al., 1996b); the situation was analogous in 2001 (87 positive cases) and 2002 (113 positive cases) (Table 8) (Kopřiva et al., 2009; SVFA, 2019). In 2002, two new vaccines (Lyssavac and Lyssagal) were used for oral vaccination against rabies. In 2003, an increased number of rabies cases were diagnosed (326 positive cases). Consequently, the State Veterinary and Food Administration of the Slovak Republic re-evaluated the effectiveness of the vaccines and came to the resolution to use the vaccine Lysvulpen.

In 2004, rabies was confirmed in 64 animals ( 4 cases in domestic and 60 in wild animals). According to the Slovak National Reference Laboratory for Rabies Zvolen, in 2005 marked reduction in positive cases was recorded. On average, red foxes account for 77.4-77.9\% of all positive cases, respectively, of all diagnosed positive cases in 1993-2019. Together with other wild animal species, this value represents more than $84 \%$ of all laboratory confirmed rabies cases (in 1993-1999: 81.3\%; in 2000-2019: 84.7\%). Rabies cases in domestic animals in 1993-1999 represented $18.7 \%$; in $2000-2019$ it was $15.3 \%$; in 2006 there were no cases. No case of rabies was diagnosed in domestic or wild animals in Slovakia in 2007 (Table 8) (Kopřiva et al., 2009; SVFA, 2019).

Slovakia was a country with no rabies status until 2012. In 2013,7 cases of rabies were confirmed in the territory of the Slovak Republic near the border with Poland ( 4 foxes, 1 marten and 2 dogs). In 2014, no cases were confirmed in Slovak Republic, but in 2015 a total of 5 cases of rabies were identified. All rabies-positive animals were foxes found in the state area near the border with Poland (Table 8) (Kopřiva et al., 2009; SVFA, 2019).

Currently, Slovakia is a rabies-free country.

The incidence of rabies in the Slovak Republic demonstrates, among other things, the effectiveness of oral rabies immunisation of red foxes - the main reservoir species of rabies. Data from the last 19 years show an improvement in the epizootiological situation in rabies. The decrease in rabies cases in domestic and farm animals corresponds with the situation in the wild ones. During last 19 years, the Slovak National Reference Laboratory for Rabies in Zvolen tested more than 54,000 animals for rabies (Table 9) (Kopřiva et al., 2009; SVFA, 2019).

\section{Conclusion}

An implementation of surveillance and monitoring programs, pre-exposition vaccination of domestic carnivores and oral vaccination of foxes are among the key activities determining successful prevention of rabies incidence in the Slovak Republic. Preventive actions must be performed effectively in the whole state territory and especially focused on the high-risk areas close to the neighboring countries with confirmed circulation of RABV.

Currently, the epizootiological situation of rabies in Slovakia is good thanks a continual oral anti-rabies vaccination of foxes. The $40^{\text {th }}$ successful vaccination campaign was performed in the autumn 2019.

Acknowledgments. This work was financially supported by the project APVV-0605-12 granted by the Slovak Research and Development Agency.

\section{References}

Anderson LJ, Williams LP, Jr, Layde JB, Dixon FR, Winkler WG., Am. J. Public Health 74, 370-372, 1984. https://doi. org/10.2105/AJPH.74.4.370

Badrane H, Bahloul C, Perrin P, Tordo N., J. Virol. 75, 3268-3276, 2001. https://doi.org/10.1128/JVI.75.7.3268-3276.2001

Blaisdell JD., Vet. Hist. 8, 22-28, 1994. https://doi.org/10.1515/ jpme.1994.22.1.28

Constantine DG., Public Health Rep. 77, 287-289, 1962. https:// doi.org/10.2307/4591470

Crandell RA., Arctic fox rabies. In Baer GM (Ed.): The natural history of rabies. CRC Press, Boca Ranton, pp. 291-306,1991.

Dietzschold ML, Faber M, Mattis JA, Pak KY, Schnell MJ, Dietzschold B., Vaccine 23, 518-524, 2004. https://doi. org/10.1016/i.vaccine.2004.06.031

Ďurove A, Ondrejka R, Švrček Š, Süliová J, Beníšek Z, Závadová J., Evaluation of effectiveness of oral rabies vaccination of red foxes in Slovakia (in Slovak). Inf. Symp. Košice (Slovak Republic), Proceedings, p. 7, 1996a.

Ďurove A, Švrček Š, Sokol J, Süliová J, Ondrejka R, Beníšek Z, Závadová J, Janusová K, Lovás B, Borsuková O, Kubinec J., Wien. Tierärztl. Mschr. 83, 158-163, 1996b.

Dutta JK, J. Indian Med. Assoc. 96, 359, 1998.

Fooks AR, Banyard AC, Horton DL, Johnson N, McElhinney LM, Jackson AC., Lancet 348, 1389-1399, 2014. https://doi. org/10.1016/S0140-6736(13)62707-5

Fooks AR, Cliquet F, Finke S, Freuling C, Hemachudha T, Mani RS, Müller T, Nadin-Davis S, Picard-Meyer E, Wilde H, Ashley C. Banyard AC., Nat. Rev. Dis. Primers 3, 17091, 2017. https://doi.org/10.1038/nrdp.2017.91

Franka R, Wu XF, Jackson FR, Velasco-Villa A, Palmer DP, Henderson H, Hayat W, Green DB, Blanton JD, Greenberg L, Rupprecht CE., Vaccine 27, 7149-7155, 2009. https:// doi.org/10.1016/j.vaccine.2009.09.034

Geue L, Schares S, Schnick C, Kliemt J, Beckert A, Freuling C, Conraths FJ, Hoffmann B, Zanoni R, Marston D, Mcelhinney L, Johnson N, Fooks AR, Tordo N, Muller T., Vaccine 26, 3227-3235, 2008. https://doi.org/10.1016/j. vaccine.2008.04.007 
Hampson K, Cleaveland S, Briggs D., PLoS Negl. Trop. Dis. 5, e982, 2011. https://doi.org/10.1371/journal.pntd.0000982

Hanlon C, Childs J., Epidemiology. In Jackson AC (Ed.): Rabies: Scientific Basis of the Disease and its Management. 3rd ed. Academic Press, Waltham MA, pp. 61-122, 2013. https://doi.org/10.1016/B978-0-12-396547-9.00003-1

Hlinka D., Slov. Vet. Čas. 6, 17-18, 2002. https://doi.org/10.7748/ ns.17.4.18.s37

Hu SC, Hsu CL, Lee MS, Tu YC, Chang JC, Wu CH, Lee SH, Ting LJ, Tsai KR, Cheng MC, Tu WJ, Hsu WC., Emerg. Infect. Dis. 24, 782-785, 2018. https://doi.org/10.3201/ eid2404.171696

ICTV (2019): Virus taxonomy. Classification and Nomenclature of Viruses. Online (10th) Report of the International Committee on Taxonomy of Viruses. https://talk. ictvonline.org/ictv-reports/ictv_online_report/ Accessed Dec. 2019.

Jeffries CL, Banyard AC, Healy DM, Horton DL, Johnson N, Fooks AR., Rabies Virus Neurovirulence. In Singh SK, Růžek D (Eds): Neuroviral Infections. CRC Press, Boca Raton, pp. 373-394, 2013.

Jiroušková M, Bačová J, Molnár A., Folia Fac. Med. Univ. Šafarikianae Cassoviensis 47, 361-368, 1990.

Johnson N, Cunningham AF, Fooks RA., Vaccine 28, 3896-3901, 2010. https://doi.org/10.1016/i.vaccine.2010.03.039

Johnson N, Phillpotts R, Fooks AR., J. Med. Microbiol. 55, 785-790, 2006. https://doi.org/10.1099/jmm.0.46370-0

Knobel DL, Cleaveland S, Coleman PG, Fevre EM, Meltzer MI, Miranda ME, Shaw A, Zinsstag J, Meslin FX., Bull. World Health Organ. 83, 360-368, 2005.

Kopřiva V, Pliešovský J, Matejčík R., Wien. Tierärztl. Mschr. 96, 1-7, 2009.

Maier T, Schwarting A, Mauer D, Ross RS, Martens A, Kliem V, Wahl J, Panning M, Baumgarte S, Müller T, Pfefferle S, Ebel H, Schmidt J, Tenner-Racz K, Racz P, Schmid M, Strüber M, Wolters B, Gotthardt D, Bitz F, Frisch L, Pfeiffer N, Fickenscher H, Sauer P, Rupprecht CE, Roggendorf M, Haverich A, Galle P, Hoyer J, Drosten C., Clin. Infect. Dis. 50, 1112-19, 2010. https://doi. org/10.1086/651267

Matouch O, Jaroš J, Vitásek J., Vzteklina v ČR a jejítlumení orální vakcinací lišek. Aktuální otázky zoonóz. Sborník referátů, Brno, 49-52, 2002.

Matouch O, Jaroš J, Vrzal V., Vet. Med. (Praha) 43, 245-248, 1998. Matouch O, Vitásek J., Rabies Bull. Eur. 26, 5-8, 2002.

Matouch O, Vitásek J, Semerad Z, Malena M., Rev. Sci. Tech. 26, 577-584, 2007. https://doi.org/10.20506/rst.26.3.1762

Muller T, Batza HJ, Beckert A, Bunzenthal C, Cox JH, Freuling CM, Fooks AR, Frost J, Geue L, Hoeflechner A, Marston D, Neubert A, Neubert L, Revilla-Fernandez S, Vanek E, Vos A, Wodak E, Zimmer K, Mettenleiter TC., Arch. Virol. 154, 1081-1091, 2009. https://doi.org/10.1007/ s00705-009-0408-7

Müller T, Schlüter H., J. Etlik Vet. Microbiol. 9, 35-39, 1998.

Nokireki T, Tammiranta N, Kokkonen UM, Kantala T, Gadd T., Transbound. Emerg. Dis. 65, 593-596, 2018. https://doi. org/10.1111/tbed.12833
Ondrejková A, Franka R, Ondrejka R, Švrček Š, Süli J, Beníšek Z, Zubrický P, Bajová V, Bugarský A, Bourhy H., Bull. Vet. Inst. Pulawy 48, 11-13, 2004.

Ondrejková A, Ondrejka R, Švrček Š, Süli J, Beníšek Z, Franka R., Slov. Vet. Čas. 25, 358-360, 2000.

Prager KC, Woodroffe R, Cameron A, Haydon DT, Biol. Conserv. 144, 1940-1948, 2011. https://doi.org/10.1016/j.biocon.2011.03.025

Singh R, Singh KP, Cherian S, Saminathan M, Kapoor S, Manjunatha Reddy GB, Panda S, Dhama K., Vet. Q. 37, 212-251, 2017. https://doi.org/10.1080/01652176.2017.1343516

Stőhr K, Meslin FX., Vet. Rec. 139, 32-35, 1996. https://doi. org/10.1136/vr.139.2.32

Strimpl V., Věstník veřejného zdravotnictví a tělesné výchovy $13,279-288,1931$.

SVFA (2019): State Veterinary and Food Administration of the Slovak Republic, Besnota. https://www.svps.sk/zvierata/choroby_besnota.asp. Accessed Dec. 2019.

Švrček Š., Oral vaccination of foxes against rabies. Methodical instructions (in Slovak). ŠVS SR, Bratislava, 12 pp, 1992.

Švrček Š, Beníšek Z, Vrtiak OJ, Závadová J, Ďurove A, Húska M, Süliová J, Ondrejka R, Paulík Š, Fejfar V, Láni D., The current epizootiological situation and immunoprophylaxis of rabies (in Slovak). I. Symposium about the diseases of carnivores. Košice (Slovak Republic). Proceedings 27-30, 1991.

Švrček Š, Ďurove A, Ondrejka R, Sokol J, Süliová J, Závadová J, Lovás B, Beníšek Z, Vrtiak OJ, Selimov MA, Žuffa T, Feketeová M, Dušeková J, Kubinec J, Žurek A, Borsuková O, Mad'ar M, Švehlíková J., Bull. Vet. Inst. Pulawy 42, 96-97, 1998.

Švrček Š, Ondrejka R, Ondrejková A, Süli J, Závadová J, Beníšek Z, Mad'ar M, Franka R., Scientific bulletin of Uzhgorod National University, Series: Biology 9, 138-141, 2001.

Švrček Š, Sokol J, Lovás B, Ďurove A, Borsuková O, Süliová J, Ondrejka R, Kubinec J, Beníšek Z, Žurek A., Epizootiological situation and control of rabies in the Slovak Republic. WHO Rabies Conference, Budapest (Hungary). Proceedings 19, 1995.

Švrček Š, Sokol J, Ondrejková A, Lovás B, Závadová J, Ondrejka R, Süliová J, Beníšek Z, Mad'ar M, Jánek F., Analysis of epizootiological situation of rabies in Slovakia and other European countries (in Slovak). Conference „Animal Health and Diseases - Current Problems of Epizootiology and Infectology“. Košice, Slovak Republic. Proceedings 24-27, 1999.

Švrček Š, Vrtiak OJ, Ďurove A, Ondrejka R, Závadová J, Süliová J, Beníšek Z, Húska M,Žuffa T, Feketeová M, Dušeková E, Šnirc J, Žurek A, Láni D, Blecha J, Mandelík M, Dušek J, Salaj J, Hojsík J, Lovás B, Gašpar P., Oral antirabies vaccine; verification of its effectiveness and harmlessness, preliminary results of the field application (in Slovak). Final Report of UVM and MEVAK a.s. Nitra, 88, 1993.

Ursíny J, Stolzová-Sutorisová M., Rabies (in Slovak). Príroda, Bratislava, pp. 113, 1970.

Wandeler AI., Oral immunization of wildlife. In Baer GM (Ed.): The Natural History of Rabies. CRC Press, Boca Raton, 485-503, 1991. 
Wandeler AI., Schweiz. Arch. Tierheilk 142, 455-462, 2000.

Wilde H, Hemachudha T, Wacharapluesadee S, Lumlertdacha B, Tepsumethanon V., Rabies in Asia: The classical zoonosis. In One health:the human-animal-environment interfaces in emerging infectious diseases. Springer,
Berlin, pp. 185-203, 2013. https://doi.org/10.1007/9783-642-36889-9

Wunner WH, Briggs DJ., PloS Negl. Trop. Dis. 4 (3), e591, 2010. https://doi.org/10.1371/journal.pntd.0000591 